\title{
Diversity of fishing gears and crafts used for harvesting the Asian seabass, Lates calcarifer along the Bay of Bengal, Bangladesh coast
}

\author{
MOHAMMED ASHRAFUL HAQUE ${ }^{1}$, MD. ISTIAQUE HOSSAIN, \\ SHANUR JAHEDUL HASAN ${ }^{1 *}$ AND PROBIN KUMAR DEY ${ }^{2}$ \\ Department of Fisheries, University of Rajshahi, Bangladesh \\ ${ }^{1}$ Marine Fisheries \& Technology Station, Bangladesh Fisheries Research Institute, Cox's Bazar 4700 \\ ${ }^{2}$ Department of Fisheries, University of Chittagong, Bangladesh \\ Corresponding Author: sunny_hasan80@yahoo.com
}

\begin{abstract}
Though Asian Seabass, which is locally known as "Koral"/"Vetki," is a vital species in terms of its popularity and price, little is known about the location of breeding and nursery ground, peak breeding season, peak harvesting season, population dynamics, harvesting operation (gears and crafts used for harvesting) of this species in Bangladesh. An investigation was carried out to enlist the group of crafts and gears that are being operated on the Bay of Bengal coast by the fishermen for Asian seabass harvesting. The survey was based on interviews with the local fishermen and secondary data collected from the regional fisheries offices. The study revealed a total of 10 distinguishing fishing gears, including seven nets and two types of hook and lines were used for harvesting this fish. Some are selective for harvesting Seabass, but most of them are involved in multi-species exploitation. Four types of motorized and two types of non-motorized traditional boats are being used for harvesting the seabass in Bangladesh. The seabass fishery extends almost throughout the year at different life stages. The Koral net, Mela Barshi (Single Hook and line), and Push net were found to be effective for catching adult, pre-adult, and juvenile Asian seabasses, respectively. The Sampan boat and Mela barshi were reported for the first time as fishing boats and fishing gear in Bangladesh.

Keywords: Fishing gear, Fishing crafts, Lates calcarifer, Bay of Bengal
\end{abstract}

\section{Introduction}

Seabass (Lates calcarifer) is one of the most important commercial coastal and marine fish of Bangladesh (Rahman 1989). This species is known by various common names in different parts of the world, including "barramundi" in Australia and "Bhetki/Koral" in Bangladesh and India (Siddik et al. 2016). The distribution of seabass does not extend to deep sea and is limited to 4060 nautical miles from the shore. In Bangladesh, Koral fish is available in coastal waters of Cox's Bazar, Chattagram, Feni, Sondwip, Hatiya, Bhola, Barisal, Patuakhali, Khulna, Bagerhat and Satkhira (Das 2000, Karmakar and Das 2001, Kamruzzaman et al. 2013, Haque et al. 2019).

Being a riverine and coastal country, boats and fishing are an integral part of the coastal life of Bangladesh. Bangladesh boasted the largest fleet of wooden boats. These fishing boats are built traditionally by the rural carpenters with wooden planks. These boats used to come in all shapes and sizes, with different functions and designs. Till the mid ' 60 s, fishing operations in the estuaries and offshore waters were carried out by traditional craft. The first initiatives of motorized fishing boats started in 1966-67 with outboard engines. Subsequently, these were replaced by inboard marine diesel engines. The motorization programme gained momentum after the country won freedom in 1971 (BOBP 1985). The marine fishing fleet consists of about 34,810 traditional boats, 32,859 motorized boats and 247 trawlers. The total number of marine

https://doi.org/10.52168/bjf.2021.33.17 
fishing gears were operated in Bangladesh was $1,88,707$. The number of marine fishermen was about 5,16,000 out of a total of 1.16 million fishermen in the country (DoF 2016). Several researchers have studied the types of fishing gears used in estuarine waters of Bangladesh (Siddique et al. 2013, Ali et al. 2014, Azam et al. 2014, Paul et al. 2019). Most literatures on crafts and gears are limited on different coastal rivers and estuaries but not targeting the particular fish species. Hence, no literature is available on crafts and gears used for harvesting the Asian seabass in Bangladesh. So, the present study was concentrated to document the different fishing gears and crafts used for harvesting the Asian seabass in Bangladesh with their detailed description.

\section{Materials and Methods}

Study area: The study was commenced in January 2019 and continued up to December 2020. During the study period, detailed data on gears and crafts which were operated along the BoB coast for capturing Seabass has been collected from some selected sampling points of the Bay of Bengal. The sampling point's encompassed five locations, such as Cox's Bazar, Chattagram, Hatya, Mohipur, Patuakhali, and Shatkhira, which predominantly cover the total coastline of the Bay of Bengal from Southeast towards Southwest. The time of the day for the survey varied from six O'clock in the morning to often eight $\mathrm{O}^{\prime}$ clock in the night. The frequency of sampling was not equal for all the sampling points due to distance and manpower shortage. In this case, fortnightly sampling was performed in a comparatively nearer distant location from the Implementing station such as Mahesh Khali and Sonadia Channel of Cox's Bazar and Mouth of Karnafully river Chittagong. Apart from the aforementioned locations of Cox's Bazar and Chattagram, far distant locations such as Hatya, Patuakhali (Mohipur and Alipur), and Shatkhira (Shyamnagar) sampling was accomplished on the basis of the season to get a complete scenario of gear diversification. In this connection, sampling season was divided into two parts such as dry (November- April) and wet (May- October). On each sampling day, 8-10 fishers were interviewed from the respective sampling point. Hired mechanized boats were used for data collection in most of the cases. Visiting fishing villages adjacent to the river bank was another approach of data collection. Data were mostly collected from fishermen while they were fishing in the estuaries and tidal canals and recorded in a structured questionnaire.

Moreover, Focus Discussion (FGD) with seabass fishers and personal interview were performed in this study. The questionnaire was prepared to collect information on aspects of any gear like local name; usual size; mesh size; method, season and persons involved in operation, carrying capacity, construction cost, life span of gear and crafts, efficiency etc. The FGD was participated by representative boat and gear owners, boat crew, head fishermen (Mazi). Crosscheck Interviews (CI) were conducted with key informants and extension workers.

Data analysis: The collected data and information were accumulated and entered into MS-excel and then presented in textual, tabular and graphical form.

\section{Results and Discussion}

Fishing crafts used for harvesting the Asian seabass in Bangladesh: From this investigation it was found that though Asian seabass is high valued popular coastal fish of Bangladesh, there is 
no any production statistics in Bangladesh. The Koral or Bhetki is an iconic and attractive fish to all coastal fishers due to its high market price. Market price varies on its body weight. The adult seabass was sold in local market of Cox's Bazar at 700 -800 BDT per kilogram. So, fishing pressure on seabass stock is very high in Bangladesh. In Focus Group Discussion, the fishermen and traders stated the declining seabass production in Bangladesh mainly due to overfishing, habitat change resulting from heavy sedimentation. In recent years, the mesh size of Koral net (a modified gillnet for Seabass harvesting) was decreased from $21 \mathrm{~cm}$ to $15 \mathrm{~cm}$ in Cox's Bazar area. In Bangladesh the major fishing of Asian seabass was based on mechanized crafts and gear. There was almost nonexistence of the primitive fishing crafts like Dug-out canoe, Bamboo raft etc. but the wooden boats used for harvesting seabass in coastal and offshore areas of Bangladesh. Generally six types of fishing boats are used in fishing of Asian seabass Lates calcarifer from the coastal and offshore waters in Bangladesh is given in Table I.

Table I. Fishing boats used for seabass ( $L$. calcarifer) harvesting in coastal areas of Bangladesh

\begin{tabular}{|c|c|c|c|c|c|c|c|c|}
\hline $\begin{array}{c}\text { Boat } \\
\text { name }\end{array}$ & Size (m) & $\begin{array}{c}\text { Bottom } \\
\text { shape \& type }\end{array}$ & $\begin{array}{l}\text { Engine } \\
\text { Power }\end{array}$ & $\begin{array}{l}\text { Carrying } \\
\text { capacity }\end{array}$ & $\begin{array}{c}\text { Man } \\
\text { power }\end{array}$ & $\begin{array}{l}\text { CPUE of } \\
\text { the Boat }\end{array}$ & Life span & Gear used \\
\hline $\begin{array}{l}\text { Wooden } \\
\text { Fishing } \\
\text { Vessel }\end{array}$ & $\begin{array}{l}\text { L:11-18 } \\
\text { Width: } 3-4 \\
\text { Depth :2-3 }\end{array}$ & $\begin{array}{c}\text { Rounded, } \\
\text { Advance } \\
\text { motorized }\end{array}$ & $\begin{array}{c}20-45 \\
\mathrm{HP}\end{array}$ & $\begin{array}{l}10-15 \\
\text { tons }\end{array}$ & $10-20$ & $\begin{array}{c}2-4 \\
\text { seabass/ } \\
\text { haul/day }\end{array}$ & $\begin{array}{c}10-12 \\
\text { Yrs. }\end{array}$ & $\begin{array}{l}\text { Gill net, } \\
\text { SBN, Purse } \\
\text { seine }\end{array}$ \\
\hline $\begin{array}{l}\text { Balam } \\
\text { boat }\end{array}$ & $\begin{array}{l}\text { L:10-15 } \\
\text { Width:3-4 } \\
\text { Depth:2-3 }\end{array}$ & $\begin{array}{c}\text { Rounded, } \\
\text { Mechanized }\end{array}$ & $\begin{array}{c}22-45 \\
\text { HP }\end{array}$ & 10 Tons & $8-10$ & $\begin{array}{c}1-3 \\
\text { seabass/ } \\
\text { haul/day }\end{array}$ & $\begin{array}{l}8-10 \\
\text { Yrs. }\end{array}$ & $\begin{array}{l}\text { Gill net, } \\
\text { Drift net } \\
\text { Long line }\end{array}$ \\
\hline $\begin{array}{l}\text { Crescent } \\
\text { shape } \\
\text { Sampan }\end{array}$ & $\begin{array}{l}\text { L: 8-10 } \\
\text { Width:2-2.5 } \\
\text { Depth:1-2 }\end{array}$ & $\begin{array}{c}\text { Rounded, } \\
\text { Mechanized }\end{array}$ & $\begin{array}{c}\text { 20-36 } \\
\text { HP }\end{array}$ & NA & $8-10$ & $\begin{array}{c}1-2 \\
\text { seabass/ } \\
\text { haul/day }\end{array}$ & $\begin{array}{l}8-10 \\
\text { Yrs. }\end{array}$ & $\begin{array}{l}\text { Seine net } \\
\text { Gillnet }\end{array}$ \\
\hline $\begin{array}{l}\text { Dingi } \\
\text { nauka }\end{array}$ & $\begin{array}{l}\text { L.:5-6 } \\
\text { Width:2-2.5 } \\
\text { Depth :1 }\end{array}$ & $\begin{array}{c}\text { Rounded, } \\
\text { Mechanized }\end{array}$ & $\begin{array}{c}\text { 18-20 } \\
\text { HP }\end{array}$ & NA & $6-8$ & $\begin{array}{c}\text { 2-6 juvenile } \\
\text { seabass/hau } \\
\text { 1/day }\end{array}$ & $\begin{array}{r}7-8 \\
\text { Yrs. }\end{array}$ & $\begin{array}{l}\text { Seine net, } \\
\text { ESBN }\end{array}$ \\
\hline $\begin{array}{l}\text { Dingi } \\
\text { nauka }\end{array}$ & $\begin{array}{l}\text { L.:6-7 } \\
\text { Width:1.5-2 } \\
\text { Depth }: 1\end{array}$ & $\begin{array}{l}\text { Rounded, } \\
\text { Non } \\
\text { mechanized }\end{array}$ & NA & NA & $1-2$ & $\begin{array}{c}3-4 \\
\text { seabass/ } \\
\text { day }\end{array}$ & $\begin{array}{l}5-6 \\
\text { Yrs. }\end{array}$ & $\begin{array}{l}\text { Hook \& } \\
\text { line, Stake } \\
\text { net }\end{array}$ \\
\hline $\begin{array}{l}\text { Kosha } \\
\text { nauka }\end{array}$ & $\begin{array}{l}\text { L.:6-7 } \\
\text { Width:1.5-2 } \\
\text { Depth :1 }\end{array}$ & $\begin{array}{c}\text { Flat, } \\
\text { Primitive }\end{array}$ & NA & NA & $1-2$ & $\begin{array}{c}1-2 \\
\text { seabass/ } \\
\text { day }\end{array}$ & $\begin{array}{l}4-5 \\
\text { Yrs. }\end{array}$ & $\begin{array}{l}\text { Hook \& } \\
\text { line, ESBN }\end{array}$ \\
\hline
\end{tabular}

Non-mechanized artisanal fishing boat: These plank built boats are covered with wooden or bamboo frames. The smaller sized boats are used in coastal rivers, canal and estuaries (e.g. Kosha, Fig. 1a) and Dingi nauka (Fig. 1b). Kosha nauka is a low cost, most traditional country boat with flat bottom and decking half split bamboo. Fishing in small tidal rivers and canals. It is propelled by long oars or bamboo pole. Dingi nauka is a small rowing boat. Most popular and common in Bangladesh. Provide low cost. It is a shallow boat with a pointed bow and the hull is strengthened by ribs and cross beams. The hulls are made of wood with decking of wood. It is propelled by long oars and/or sail operated by one or two fishermen. 


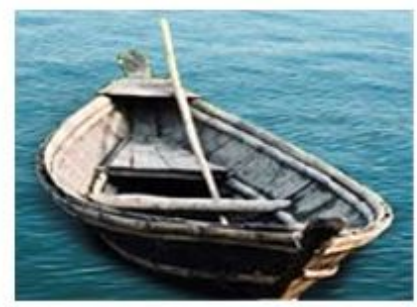

Fig. 1a. Kosha boat

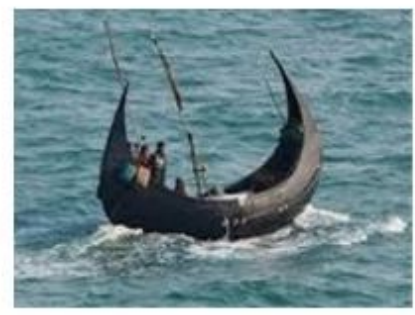

Fig. 1d. Sampan

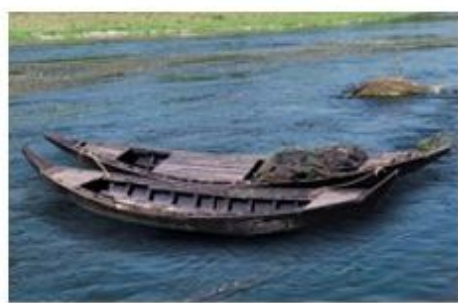

Fig. 1b. Dingi boat

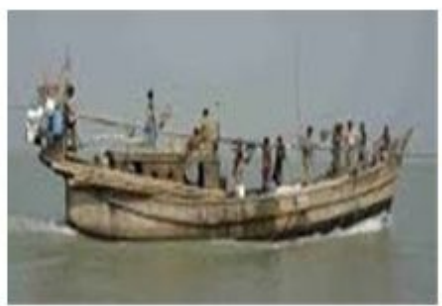

Fig. 1e. Balam boat

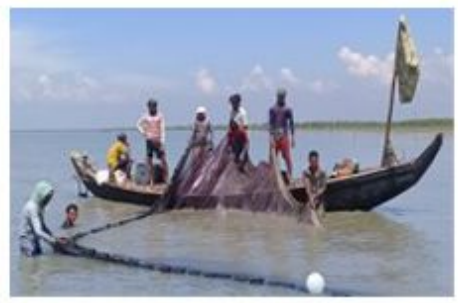

Fig. 1c. Meachanized Dingi boat

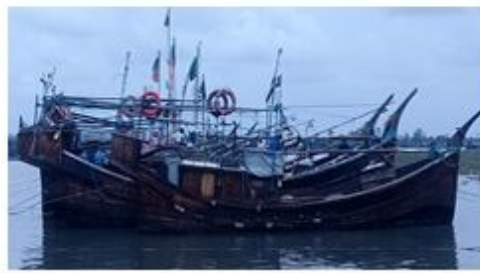

Fig. 1f. Wooden Trawler

Fig. 1. Different types of crafts used for catching the Asian seabass.

Motorized country boats and dingi boats: Medium sized boats are mainly used in commercial fishing. These boats are also used for harvested fish transportation. e.g. Motorized Dingi (Fig. 1c), Sampan (Fig. 1d) and Balam boat (Fig. 1e). Motorized dingi boats are of the same design and structure to non-mechanized Dingi but large in size, powered by marine engine. Sampan fish boats are crescent shaped boats indigenous to Cox's Bazar and Chattagram region (Fig. 1e). Front head of Sampan is high and curved, but backside strait. In earlier times, these Sampans are mid-sized fishing vessels sail out to the open sea with the tide, allowed to sail in either direction only to return with the next. With the introduction of the marine engine the primary utility of the shape has forgone. The bow and stern Balam fishing boat are slightly raised. The sides are built by fitting planks to the dug-out portion of the hull. These mechanized boats are suitable for operating all types of gear and all through the seasons.

Wooden Fishing Vessel: The seagoing mechanized fishing vessels (locally termed as trawler, Fig. 2f) are made from the best quality planks and are covered with wooden frames having a cabin, a kitchen and latrine facilities. These fishing vessels should be registered from Mercantile Marine Department, is well equipped with all life savings materials. They have insulated cold storage facilities for preserving the harvested fishes up to 15 days in the sea. These large sized boats vary in size.

Seabass harvesting gears in Bangladesh coast: In the present study, as many as ten kinds of fishing gears have been recorded which were used for harvesting the Asian seabass in Bangladesh. The materials used for making the seabass fishing gears include tire cod thread, twine, plastic floats, nylon ropes, lights, hook, polyethylene, nylon, cotton, polypropylene, mixed fibers, floats and sinkers, bamboo, etc. Based on the mode of operation, the gears 
MOHAMMED ASHRAFUL HAQUE et al.

encountered for seabass fishing in Bangladesh coast have been classified into different types as shown in Table II.

Table II. Types of net used for fishing Asian seabass in the northeast part of Bangladesh coast

\begin{tabular}{|c|c|c|c|c|c|c|}
\hline $\begin{array}{l}\text { Gear Type/ } \\
\text { Local Name }\end{array}$ & $\begin{array}{c}\text { Type, Shape \& } \\
\text { size }\end{array}$ & $\begin{array}{l}\text { Cost (BDT) } \\
\text { Life span }\end{array}$ & $\begin{array}{l}\text { Mesh Size } \\
(\mathrm{cm}), \text { thread }\end{array}$ & $\begin{array}{l}\text { Nos. of } \\
\text { Fishers }\end{array}$ & Target fish & $\begin{array}{c}\text { Fish size/ } \\
\text { Season }\end{array}$ \\
\hline $\begin{array}{l}\text { Gill net } \\
\text { (Koral jal) } \\
\text { with sinker }\end{array}$ & $\begin{array}{l}\text { Selective, } \\
\text { Rectangular, } \\
\text { L:200-500 m } \\
\text { W:6-7 m }\end{array}$ & $\begin{array}{l}1,50,000- \\
1,80,000 \\
8-10 \text { years }\end{array}$ & $\begin{array}{c}15 \mathrm{~cm}(9 / 3 \\
\text { nylon), } 21 \mathrm{~cm} \\
(45 / 3 \text { nylon } \\
\text { thread })\end{array}$ & $8-10$ & Asian seabass & $\begin{array}{l}\text { Adult, } \\
\text { March to May }\end{array}$ \\
\hline $\begin{array}{l}\text { Shore seine } \\
\text { (Tana Ber jal) }\end{array}$ & $\begin{array}{l}\text { Nonselective, } \\
\text { Rectangular, } \\
\text { L:50 -200 m } \\
\text { W:5-6 m }\end{array}$ & $\begin{array}{l}80,000- \\
1,00,000 \\
4-5 \text { years }\end{array}$ & $1.0-2.3$ & $8-12$ & $\begin{array}{l}\text { Multi-fishery } \\
\text { including } \\
\text { seabass }\end{array}$ & $\begin{array}{l}\text { Juvenile, } \\
\text { Sept. to Dec. }\end{array}$ \\
\hline $\begin{array}{l}\text { Set bag net } \\
\text { (Behundi jal) }\end{array}$ & $\begin{array}{l}\text { Nonselective, } \\
\text { Conical } \\
\text { L: } 12-15 \mathrm{~m}\end{array}$ & $\begin{array}{l}1,00,000- \\
1,50,000 \\
4-5 \text { years }\end{array}$ & $\begin{array}{c}5 \text { to } 6 \text { and } 0.5 \\
\text { to } 1.25 \text { Nylon } \\
\text { thread }\end{array}$ & $2-6$ & $\begin{array}{l}\text { Multi-fishery } \\
\text { including } \\
\text { seabass }\end{array}$ & $\begin{array}{l}\text { Juvenile } \\
\text { Sept. to Dec. }\end{array}$ \\
\hline $\begin{array}{l}\text { Drag net } \\
\text { (Kukkuru jal }\end{array}$ & $\begin{array}{l}\text { Nonselective, } \\
\text { Rectangular, } \\
\mathrm{L}: 15-20 \mathrm{~m} \\
\mathrm{~W}: 2.0 \mathrm{~m}\end{array}$ & $\begin{array}{l}10,000 \\
3-4 \text { years }\end{array}$ & $\begin{array}{c}1.0-2.0 \\
\text { Nylon thread }\end{array}$ & 2 & $\begin{array}{l}\text { Multi-fishery } \\
\text { including } \\
\text { seabass }\end{array}$ & $\begin{array}{l}\text { Juvenile, } \\
\text { Sept. to Dec. }\end{array}$ \\
\hline $\begin{array}{l}\text { Stake net } \\
\text { (Char ghera } \\
\text { jal) }\end{array}$ & $\begin{array}{l}\text { Nonselective, } \\
\text { Half circle } \\
\text { L:200-300 m } \\
\text { W: } 2.5-3 \mathrm{~m}\end{array}$ & $\begin{array}{l}50,000- \\
60,000 \\
4-5 \text { years }\end{array}$ & $\begin{array}{c}0.8-1.0 \\
\text { Nylon thread }\end{array}$ & $1-2$ & $\begin{array}{l}\text { Multi-fishery } \\
\text { including } \\
\text { seabass }\end{array}$ & $\begin{array}{l}\text { Adult, } \\
\text { juvenile } \\
\text { Sept. to Dec. }\end{array}$ \\
\hline $\begin{array}{l}\text { Cast net } \\
\text { (Jakhi jal) }\end{array}$ & $\begin{array}{l}\text { Nonselective, } \\
\text { Conical }\end{array}$ & 5000 to 10000 & $\begin{array}{c}0.6 \text { to } 1.25 \\
\text { Handmade } \\
\text { Nylon thread }\end{array}$ & 01 & $\begin{array}{l}\text { Multi-fishery } \\
\text { including } \\
\text { seabass }\end{array}$ & $\begin{array}{l}\text { Juvenile } \\
\text { All seasons }\end{array}$ \\
\hline $\begin{array}{l}\text { Push net } \\
\text { (Fenni jal, } \\
\text { Thela jal) }\end{array}$ & $\begin{array}{l}\text { Nonselective, } \\
\text { Triangular }\end{array}$ & $200-1000$ & 0.5 & 01 & $\begin{array}{l}\text { Multi-fishery } \\
\text { including } \\
\text { seabass }\end{array}$ & $\begin{array}{l}\text { Larvae, } \\
\text { Juvenile } \\
\text { Monsoon }\end{array}$ \\
\hline $\begin{array}{l}\text { Single hook \& } \\
\text { line } \\
\text { (Mela Barshi) }\end{array}$ & $\begin{array}{c}\text { Selective } \\
5-8 \text { Nos } \\
\text { Steel hook } \\
\end{array}$ & $300-500$ & $\begin{array}{c}\text { Monofilament } \\
\text { glass fiber } \\
\text { fishing line }\end{array}$ & 01 & Asian seabass & $\begin{array}{l}\text { Adult, pre } \\
\text { adult } \\
\text { Aug.- March }\end{array}$ \\
\hline $\begin{array}{l}\text { Long line } \\
(2000-3000 \\
\text { hook) }\end{array}$ & $\begin{array}{c}\text { Non selective } \\
5-6 \text { Nos } \\
\text { Steel hook }\end{array}$ & $\begin{array}{l}50,000- \\
60,000 \\
4-5 \text { years }\end{array}$ & $\begin{array}{l}\text { Rope made by } \\
\text { Tire cod thread }\end{array}$ & $10-12$ & $\begin{array}{l}\text { Multi-fishery } \\
\text { including } \\
\text { seabass }\end{array}$ & $\begin{array}{l}\text { Adult, pre } \\
\text { adult } \\
\text { Sept.- March }\end{array}$ \\
\hline
\end{tabular}

\section{Nets used in harvesting Asian seabass}

Koral jal (Gill net): The Koral jal (Fig. 2a,c), which is a modified version of the large meshed gill net, the local fishers developed for harvesting seabass in Cox's Bazar region. The vertical wall of the net sets out in a straight line with a mesh opening for entangling adult seabass. A large numbers of pieces are joined together to make long nets. Floats and sinkers are attached with plastic ropes which are used as head ropes and weight.

Behundi jal (Set bag net): Behundi jal is a conical shaped net and has two extensions (Fig. 2b). In traditional practice the net is made up of nylon ropes and is knotted. Mouth of the net is spread and fixed on tide by bamboo, wood or iron. Fish is trapped in the centre pouch of the net. 
Char Ghera jal (Set Barrier net): Char ghera jal is used to catch fish from accreted river banks inundated during high tide. Net fencing is made by wooden pole at a distance of 3-4 feet are inserted in the soil-bed to support the net during high tides. (Fig. 2d).

Tana Ber jal (Shore Seine net): Ber jal (Fig. 2e) is a fine meshed seine net which is commonly used in shore or beach area. After surrounding the part of a water body with this net, the two ends of the net are drawn together and the ground rope is hauled up from the center of the water body to catch the fish.

Kukkuru jal (Drag net): Kukkuru jal (Fig.2f)) is a fine mesh size seine net which is commonly used in shore area. Two bamboo poles are fixed to the ends of the net. The plastic floats are tied with the upper rope. Two fishermen operate the net by holding the bamboo vertical.

Jhaki jal (Cast Net): Cast net is operated in marginal water areas from land. The net is conical shaped with a strong rope attached to the apex (Fig. 2g). A number of weights of iron or lead are attached along the margin. The fisherman throws the net skillfully over the water, in such a way that the rope is held in one hand and the net falls on the water surface fully expanded. The net gradually sinks to the bottom due to weights attached to the margin, and various fish including juvenile seabass and prawn are entangled in it. The net is hauled with the help of rope.

Thella jal (Push Net): Also known as Fenni jal. This net is made by triangular framed bamboo with small mesh size (Fig. 2h). It is usually operated in the shallow marginal area and floodplain lagoon. It is lowered into water and lifted out in a scooping style. The net is made up of mosquito net to catch the seabass fries, small fish and prawns.

Hooks and lines used in seabass catch : " $\mathrm{J}$ " shaped steel hook is mostly used for hook and line fishing. Two types of hooks and lines were recorded for fishing the Asian seabass in the study area (Table II).

Mela Barshi (Single hook and line): Mela Barshi (Fig. 2i) is mainly use to catch seabass by using baits in Cox's Bazar area. It operated from boat, hook tied with one end of a line and the other end with a bamboo roll. Live big size tiger shrimp, Mullet fish used as a bait. The thick nylon tread line is controlled by fisher's hand due to baited mega sized seabass is difficult for controlling under water. Target of this gear is seabass (Lates calcarifer). Hooked Koral are tied with nylon rope at river water in live condition during rest fishing.

Long line seabass fishing: Long-lining (Fig. 2j) is a fishing method that involves setting out a large number of short nylon lines carrying hooks, which are attached to a longer main line at regular intervals. The longlines bear 1,000 to 2,000 hooks, mainly used for catching croaker, seabass, threadfin, catfish, eel, snapper, etc. Long lines with chain snoods and big shark hooks are also used for catching sharks and rays. It exploits waters at depths between 10 and 25 fathoms. 


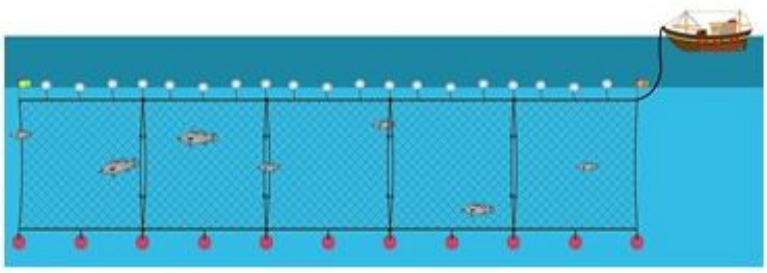

Fig. 2a. Koral net (Modified Gill net)

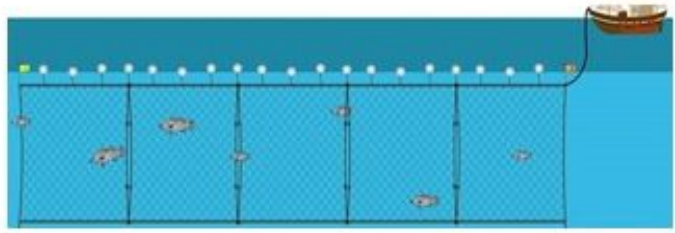

Fig. 2c. Koral net (Modified Gill net without weight)

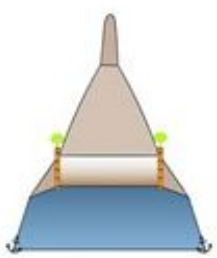

Fig. 2b. Set Bag Net

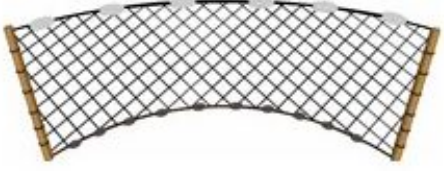

Fig. 2e. Drag net (Kukkuru jal)

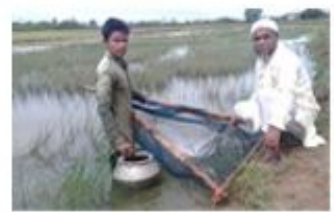

Fig. 2h. Push net (Fenni jal)

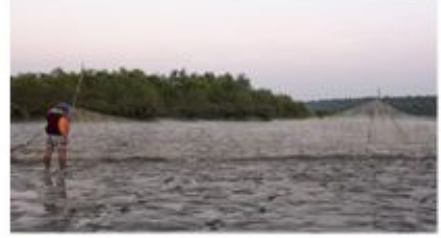

Fig. 2f. Stake net (Char ghera jal)

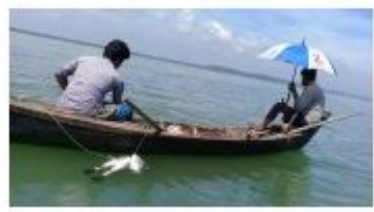

Fig. 2i. Hook \& line (Mela Barshi)

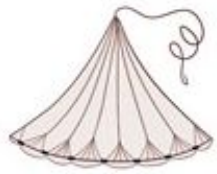

Fig. $2 \mathrm{~g}$. Cast net

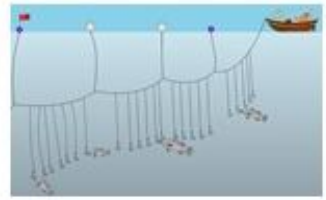

Fig. $2 \mathrm{j}$. Long line

Fig. 2. Different types of nets and gears used for catching the Asian seabass.

Haque et al. (2020) reported the gillnet was used for catching the running ripe Asian seabass in Fadar char seabass spawning ground in Cox's Bazar, of Bangladesh. Similar findings were reported by Maneewongsa and Tattanon (1982) in Songkhla lake, Thailand. They reported that gillnets, hooks and lines, cast nets and traps were used to catch the mature seabass. Moore (1982) also reported the adult seabass were harvested by gillnet from spawning ground and juvenile seabass were collected by beach seine from Papua New Guinea. Hameed and Boophendranath (2000) recorded that fishing gears materials include netting, twine, plastic structural and fasteners, clips and swivels, ropes, steel wire ropes, combination wire ropes, purse rings, polyester, polyethylene, nylon, cotton, polypropylene, mixed fibers, floats and sinkers, bamboo, wood etc. The form and size of the gear depends on the use of gears and the environmental condition of the water body. Some Indian researchers recorded that gill net, seine 
net, bag net, cast net, drag net, stake net, scope net, hook \& line and traps are used in Indian coast for commercial fishing (Mitra et al. 1997, Bakta et al. 2017).

So far numbers of researches have been conducted in different coastal rivers of Bangladesh to document the available crafts and gears which are in use for fishing. Ahmed (1961) reported Phansh jal, Apsha jal (gill net) and Tana berjal, Patan jal (Seine net) were used for seabass fishing in coastal areas of Bangladesh. Chakraborty et al. (1995) reported that the major fishing gears of Bangladesh were fishing nets, fishing traps, hooks and lines, wounding gears and fish aggregation device. Islam et al. (2016) documented that a total of 2 gill net, 1 fixed purse net, 1 cast net, 1 dip net, 2 traps, 2 hooks and lines and 2 wounding gears were found in the Rupsa river, Khulna. Ali et al. (2015) found that eight major types of fishing gears were used to harvest fish in Ramnabad river, Patuakhali including gill nets, seine nets, lift nets, push nets, cast nets. Fishing traps i.e, Polo, Bana and hook and line.

From the indigenous knowledge of Seabass fishers of Bangladesh, it is clear that due to use of some destructive fishing gears (Set bag net, Shore seine, Push net etc.) that overfishing the running ripe gravid seabass from spawning ground, also the larvae and juveniles of seabass from the natural waterbody, causes the serious depletion of seabass as well as to the marine and coastal biodiversity of Bangladesh. In the present study, as many as ten types of fishing gears have been documented. Among the documented gears and crafts, one new gear (single hook and line) and one fishing boat (Sampan) were found to be involved in Seabass harvesting at BoB coast, which earlier has not been reported from Bangladesh. This finding can help to catch seabass with suitable size; also will help to protect the seabass as well as to reduce the loss of fish biodiversity.

Acknowledgements: The authors gratefully acknowledge National Agricultural Technology Program II Project (NATP-2) BARC Component, Bangladesh Agricultural Research Council, Farmgate, Dhaka, and Marine Fisheries Research Strengthening and Infrastructural Development Project under BFRI and the seabass fishers who cordially help during the study.

\section{Literature Cited}

Ahmed N., 1961. Fishing Gear of East Pakistan. Government of East Pakistan Directories of Fisheries. $35 p$.

Ali, M.M., B.C. Das, S.M.A. Islam, M.A. Masud and M.Z. Rahman, 2014. Fishing gears and crafts used by the fishers at Lohalia River in Patuakhali. J. Environ. Sci. Nat. Resour., 7(2): 169-175.

Ali, M.M, M.B. Hossain, M.A. Masud and M.A Alam, 2015. Fish species availability and fishing gears used in Ramnabad River, southern Bangladesh. Asian J. Agric. Res., 9(1): 12-22.

Azam, A.K.M.S., D. Saha, M. Asadujjaman, K.R. Mahbub and M.H. Minar, 2014. Fishing gears and crafts commonly used at Hatiya Island: A coastal region of Bangladesh. Asian J. Agric. Res., 8(1): 51-58.

Bhakta, D., W.A. Meetei, G. Vaisakh, S. Kamble, T.N. Chanu and S.K. Das 2017. An account of indigenous fishing gears of Narmada estuary, Gujarat, India. J. Indian Soc. Coast. Agric. Res., 35(1): 76-81.

BOBP, 1985. Marine small scale fisheries of Bangladesh: A general description. BOBP/INF/8. Bay of Bengal Programme, FAO, Madras, India. 59p.

Chakraborty, S.C., M.A. Hossain and M.E. Hoq, 1995. Traditional inland fishing methods in Bangladesh. J. Asiat. Soc. Bangladesh Sci., 21(1): 19-27. 
MOHAMMED ASHRAFUL HAQUE et al.

Das, N.G., 2000. Development of breeding technology of Bhetki (Lates calcarifer). Bangladesh Agricultural Research Council (BARC), 18p.

DoF, 2016. National Fish Week Compendium. 2016 Compendium Department of Fisheries, Ministry of Fisheries and Livestock, Bangladesh. 148p. (In Bengali)

Hameed, M.S. and M.R. Boophendranath, 2000. Modern Fishing Gear Technology, Das Publishing House, Dellhi, 3p.

Haque, M.A., M.I. Hossain, S.A. Uddin and M.A.M. Siddique, 2020. First onboard fertilization of the Asian seabass, Lates calcarifer: effects of egg stocking density on the fertilization, hatching and survival rate. Egyptian J. Aquatic Biol. Fish., 24(7): 145 - 154.

Haque, M.A., M.I. Hossain, S.A. Uddin and P.K. Dey, 2019. Review on distribution, culture practices, food and feeding, brood development and artificial breeding of Seabass, Lates calcarifer (Bloch 1790): Bangladesh perspective. Res. Agric. Livest. Fish., 6 (3): 405-414.

Islam M. K, S. A. Nahid, M. S. R. Khan, M .E. Ahsan, K. A. Habib and M. M. Ali, 2016. Fishing gears used by the Fishers at Rupsha River in Khulna District, Bangladesh. Int. J. Fish. Aquatic Stud., 4(1): $29-33$

Kamruzzaman, S., S.M. Al Noor and M.D. Hossain, 2013. Food and feeding habits of juvenile white sea bass, Lates calcarifer (Bloch) from the Shibsha river in the South-Western coastal region of Bangladesh. J. Bio-Sci., 21: 141-144.

Karmaker, J.K. and N.G. Das, 2001. Food and feeding habits of the bhetki, Lates calcarifer (Bloch). Bangladesh J. Zool., 29(2): 187-192.

Mahmud, S., M.L. Ali and M.M. Ali, 2015. Present scenario on livelihood status of the fishermen in the Paira River, Southern Bangladesh: Constraints and recommendation. Int. J. Fish. Aquatic Stud., 2(4): 23-30.

Maneewongsa S. and T. Tattanon, 1982. Collection and selection of Seabass spawners. In: Report of training course on Seabass spawning and larval rearing, Songkhla, Thailand. June 1982. FAO/SCS/GEN/82/39.

Mitra P.M., H.C. Karmakar, M. Sinha, A. Ghosh and B.N. Seigal, 1997. Fisheries of the Hoogly-Matlah estuarine system-An appraisal. ICAR, Barrackpore, West Bengal, India.49p.

Moore, R. 1982. Spawning and early life history of Barramundi, Lates calcarifer (Bloch), in Papua New Guinea. Austral. J. Mar. Freshwat. Res., 33: 647-61.

Paul, A.K., S. Ray, M.S. Islam, S.K. Bashak, N.M. Noor, M. De and S. K. Das, 2019. A survey on variation and availability of fishing gears and crafts in Tulsiganga river, Bangladesh. Aquaculture, Aquarium, Conservation and Legislation. Bioflux, 12(1): 51-58.

Rahman, A.K.A., 1989. Freshwater Fishes of Bangladesh. Zoological Society of Bangladesh. Department of Zoology, University of Dhaka, Bangladesh.

Siddik, M.A.B., M.A. Islam, M.A. Hanif, M.R. Chaklader and R. Kleindienst, 2016. Barramundi, Lates calcarifer (Bloch, 1790): a new dimension to the fish farming in coastal Bangladesh. J. Aquac. Res. Dev., 7: 1-3.

Siddique, A.B., D. Saha, M. Rahman and M.B. Hossain, 2013. Fishing gears of the Meghna river estuary of Chandpur region, Bangladesh. Trends in Fish. Res., 2(1): 1-8.

(Manuscript received: 25 June 2021) 